\title{
IDENTIFIKASI KUMAN PADA PUS DARI LUKA INFEKSI KULIT
}

\author{
Evy Ratnasari Ekawati ${ }^{1)}$, Siti Nur Husnul Y. ${ }^{2)}$, Dheasy Herawati ${ }^{3)}$ \\ ${ }^{1)}$ Prodi D-IV TLM, Fakultas Ilmu Kesehatan, Universitas Maarif Hasyim Latif \\ ${ }^{2,3)}$ Prodi D-III, Fakultas Ilmu Kesehatan, Universitas Maarif Hasyim Latif \\ E-mail: evysains@dosen.umaha.ac.id
}

\begin{abstract}
Infectious lesions on the skin surface are easily colonized by various organisms. Pyogenic infections are still common, especially in developing countries and for therapeutic treatment is a big challenge. Ensure appropriate and efficient therapy, inflammation-focused identification and treatment is needed. The aim of this research was to identify germs isolated from pus sample in patients suffering from wound infentions on the skin surface. The type of this research is descriptive explorative. Pus sample were taken from two people who had an infection wound on the skin surface. In this research was found Pseudomonas aeruginosa with a similarity percentage of $90.7 \%$ and Staphylococcus aureus with a percentage similarity of $91.5 \%$ in the pus sample.
\end{abstract}

Keyword: Germs, Pus, Wound Skin Infections

\section{PENDAHULUAN}

Infeksi piogenik merupakan infeksi yang ditandai dengan terjadinya peradangan local yang parah dan biasanya dengan pembentukan nanah (pus). Infeksi piogenik dikarenakan adanya invasi dan multiplikasi mikroorganisme pathogen di jaringan sehingga mengakibatkan luka pada jaringan dan berlanjut menjadi penyakit, melalui berbagai mekanisme seluler dan umumnya disebabkan oleh salah satu kuman piogenik (Singh et al., 2013).

Infeksi piogenik menyebabkan beberapa penyakit umum, diantaranya impetigo, osteomyelitis, sepsis, artritis septik, spondylodiscitis, otitis media, sistitis dan meningitis. Infeksi piogenik menghancurkan neutrophil melalui pelepasan leukosidin sehingga terbentuk abses. Hal tersebut merupakan ciri khas infeksi yang disebabkan oleh Staphylococcus aureus (Miller and John, 2011).

Komplikasi yang timbul dari infeksi kulit dan jaringan lunak karena Staphylococcus aureus merupakan masalah klinis yang utama. Hal ini dikarenakan tingginya kejadian infeksi dan munculnya strain kuman resisten antibiotik secara luas. Oleh karena itu kuman yang menghasilkan leukosidin disebut sebagai kuman piogenik (Qureshi et al., 2004).

Luka infeksi pada permukaan kulit mudah di kolonisasi oleh berbagai macam organisme (Matsuura, 2013; Anvarinejad, 2015). Beberapa penelitian menunjukkan adanya beberapa macam kuman berbeda yang diisolasi dari pasien yang tinggal di area dengan geografis berbeda (Hadadi et al., 2014; Akhi et al., 2015). Mikroorganisme penyebab radang adalah golongan kuman piogenik (Singh et al. 2013).

Kelompok kuman piogenik terdiri dari banyak spesies yang tersebar luas di tubuh manusia. Diantaranya yang paling umum adalah Staphylococcus aureus, Staphylococcus epidermidis, Streptococcus pyogenes, Escherichia coli, Streptococcus pneumonia, Klebsiella pneumonia, Salmonella typhi, Pseudomonas aeruginosa, Neisseria gonorrhoeae, Mycobacterium tuberculosis dan lain-lain (Androulla, 1989; Singh et al., 2013).

Infeksi piogenik masih sering terjadi terutama di negara-negara berkembang dan 
untuk terapi pengobatannya merupakan tantangan yang cukup besar, meskipun sudah ada kemajuan dalam teknik pemeriksaan mikrobiologi, antibiotik dan perawatan paska bedah. Untuk memastikan terapi yang sesuai dan efisien, perlu dilakukan identifikasi dan pengobatan yang terfokus pada peradangan (Chong and Kian, 2009).

Penelitian ini bertujuan untuk mengidentifikasi kuman yang diisolasi dari sampel pus dari pasien yang menderita luka infeksi pada permukaan kulit.

\section{METODOLOGI PENELITIAN}

Jenis penelitian ini adalah penelitian deskriptif eksploratif yang didapatkan berupa data jenis-jenis bakteri penyebab infeksi piogenik yang terdapat pada sampel pus (nanah). Pengambilan sampel pus (nanah) dilakukan pada dua orang yang mengalami trauma pada permukaan kulit dan terjadi peradangan selama 3 hari.

\section{Waktu dan Tempat Penelitian}

Pengambilan sampel pus pada pasien dengan luka infeksi di kulit dilakukan pada bulan 26Juni 2017. Proses isolasi dan identifikasi dilakukan pada 27 Juni 2017 sampai 3 Juli 2017. Proses purifikasi kuman dilakukan pada 4 Juli 2017 sampai 7 Juli 2017.

Pengumpulan Sampel :Pus (nanah) diambil dari pasien yang mengalami luka infeksi pada permukaan kulit dengan cara di swab menggunakan swab steril, kemudian dimasukkan kedalam tabung yang berisi media Amies. Total ada 2 sampel $\left(\mathrm{P}_{1}\right.$ dan $\left.\mathrm{P}_{2}\right)$ untuk diteliti.

Isolasi dan Identifikasi Mikroorganisme dari sampel pus (nanah) :Sampel pus (nanah) diinokulasikan pada media Nutrient Agar secara 32rganis dan diinkubasi selama 24 jam pada suhu $37^{\circ} \mathrm{C}$. Diambil 1-2 koloni terpisah yang tumbuh pada media Nutrient Agar dan diinokulasikan pada media diferential, seperti
MacConkey Agar, Eosin Methylen Blue Agar, Blood Agar Plate, Manitol Salt Agar, media Uji Biokimia Reaksi dan uji-uji pendukung, seperti uji katalase,dan koagulase.

Pengamatan Morfologi kuman : dibuat preparat dari koloni kuman yang tumbuh pada media diferensial dan dilakukan pewarnaan Gram.

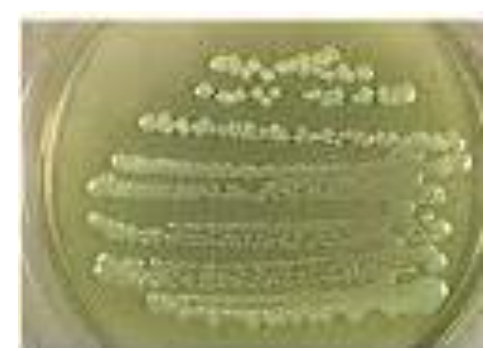

Gambar 1 Koloni kuman $\left(\mathrm{P}_{1}\right)$ yang tumbuh pada media NAP

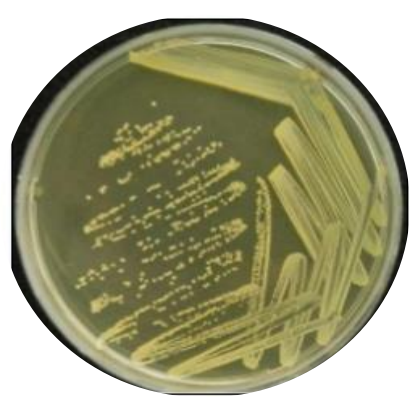

Gambar 2 Koloni kuman $\left(\mathrm{P}_{2}\right)$ yang tumbuh pada media NAP

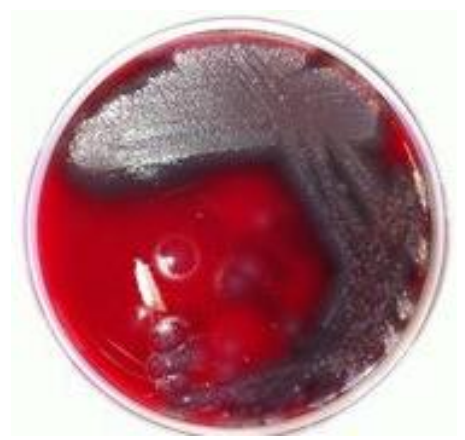

Gambar 3 Koloni kuman $\left(\mathrm{P}_{1}\right)$ yang tumbuh pada media BAP 


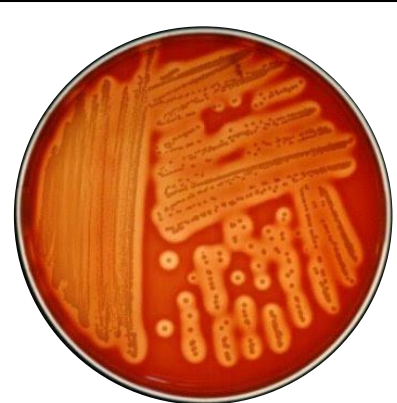

Gambar 4 Koloni Kuman $\left(\mathrm{P}_{2}\right)$ yang tumbuh pada media BAP

\section{HASIL DAN PEMBAHASAN}

\section{Hasil}

Dari hasil penelitian isolasi dan identifikasi terhadap sampel pus (nanah) didapatkan kuman Pseudomonas aeruginosa dan Staphylococcus aureus. Dari hasil uji indeks similaritas didapatkan hasil bahwa kuman dari sampel $\mathrm{P}_{1}$ merupakan Pseudomonas aeruginosa dengan prosentase kemiripan sebesar $90,7 \%$ dan pada sampel $\mathrm{P}_{2}$ merupakan kuman Staphylococcus aureus dengan prosentase kemiripan sebesar 91,5\%. Hasil isolasi dan identifikasi di sajikan pada Tabel 1.

Dari pengamatan preparat dari sampel $\mathrm{P}_{1}$ didapatkan gambaran bakteri basil Gram negatif, sedangkan dari sampel $\mathrm{P}_{2}$ didapatkan morfologi bakteri kokus Gram positif.

Tabel 1 Hasil Isolasi dan Identifikasi Sampel Pus dari Luka Infeksi Kulit

\section{Pembahasan}

Pemeriksaan berbagai 33rganism klinis diperlukan untuk diagnosis yang akurat dan menentukan strategi pengobatan yang tepat. Beberapa kondisi klinis dapat menyebabkan akumulasi pus dan sebagai sumber infeksi utama karena menyediakan lingkungan lembab untuk pertumbuhan pathogen serta menyebarkan infeksi. Sampel pus merupakan infeksi piogenik yang ditandai dengan peradangan 33rgan yang biasanya disebabkan oleh bakteri piogenik, hal ini menyebabkan lekosit mati dan akumulasi agen infeksius (Koneman et al., 2005; Sharma et al., 2015).

\begin{tabular}{clc}
\hline Kode & \multicolumn{1}{c}{ Hasil } & $\begin{array}{c}\text { Indeks } \\
\text { Similaritas } \\
\text { Sampel }\end{array}$ \\
$\mathrm{P}_{1}$ & $\begin{array}{l}\text { Pseudomonas } \\
\text { aeruginosa }\end{array}$ & $90,7 \%$ \\
$\mathrm{P}_{2}$ & $\begin{array}{l}\text { Staphylococcus } \\
\text { aureus }\end{array}$ & $91,5 \%$ \\
\hline
\end{tabular}

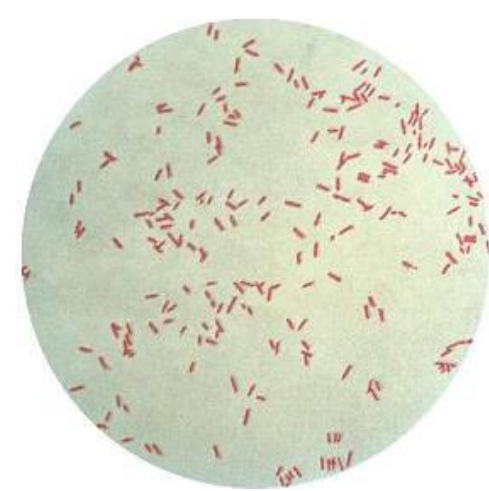

Gambar 5 Hasil pengamatan preparat sampel $\mathrm{P}_{1}$

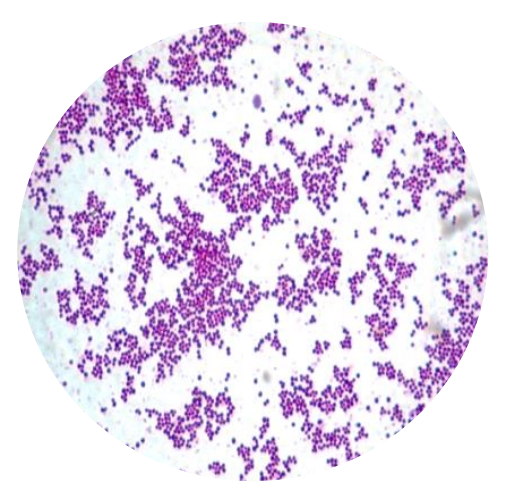

Gambar 6 Hasil pengamatan preparat sampel $\mathrm{P}_{2}$

Bakteri penghasil pus (nanah) yang paling sering adalah Staphylococcus aureus, Klebsiella spp., Pseudomonas spp., Escherichia coli, dan Streptococcus spp., dimana Staphylococcus aureus merupakan bakteri tersering yang menghasilkan pus (nanah) pada luka (Kumar, 2013).

Pada penelitian ini, didapatkan 2 jenis kuman dari hasil isolasi pus (nanah), yaitu Psudomonas aeruginosa dan Staphylococcus aureus. Penelitian yang pernah dilakukan oleh Raytekar (2017) pada sampel pus dari luka radang kulit yang di terima dari laboratorium 
mikrobiologi selama periode Februari-Oktober 2016, ditemukan Pseudomonas aeruginosa.

Pada penelitian Yasmeen (2014), hasil dari identifikasi sampel pus (nanah) luka operasi ditemukan adanya Staphylococcus aureus.

Terdapat 140 lebih spesies dari genus Pseudomonas, termasuk spesies Pseudomonas aeruginosa (Adedeji et al., 2007). Pseudomonas aeruginosa merupakan kuman Gram negatif pathogen yang sulit diobati. Resistensinya terhadap pengobatan menyebabkan kegagalan pengobatan. Pseudomonas aeruginosa cenderung tumbuh pada lingkungan yang lembab. Pseudomonas aeruginosa merupakan penyebab utama kematian karena dikaitkan dengan resistensi terhadap 34rganism34c dan tingkat kematian yang tinggi karena kesulitan dalam mengobati (Srifeungfung, 2004). Banyak penelitian yang melaoprkan tingkat kematian karena resistensi Pseudomonas terhadap obat. Betalaktamase, penisilinase, sefalosporinase dan karbapenem merupakan bagian dari mekanisme pertahanan dari Pseudomonas(Anathanarayan and Jayarampaniker, 2009).

Staphylococcus aureus merupakan kuman berbentuk kokus Gram positif bila diamati secara mikroskopis, sebagai 34rganism individual, berpasangan dan kelompok. Staphylococcus adalah bakteri non-motil, tidak berspora, katalase positif dan merupakan bagian dari flora normal manusia yang dapat ditemukan di daerah aksila, inguinal, perineum dan nares interior (Eiff et al., 2001; Yasmeen, 2014). Mikroorganisme ini menghasilkan toksin yang dapat menyebabkan penyakit atau sindrom spesifik dan dapat menyebabkan pathogenesis infeksi Stafikokokus (Faden et al., 2010).

\section{KESIMPULAN}

Penelitian ini difokuskan pada isolasi bakteri pathogen penyebab infeksi piogenik dari sampel pus (nanah) yang menyebabkan berbagai penyakit pada manusia. Pada penelitian ini ditemukan Pseudomonas aeruginosa dengan prosentase kemiripan sebesar 90,7\% dan Staphylococcus aureus dengan prosentase kemiripan sebesar 91,5\% pada sampel pus (nanah).

\section{UCAPAN TERIMAKASIH}

Penulis mengucapkan terimakasih kepada DIPA Direktorat Riset dan Pengabdian Kepada Masyarakat (DRPM) Kementrian Riset, Teknologi dan Pendidikan Tinggi atas biaya penelitian yang diberikan sehingga penelitian dapat dilakukan hingga selesai.

Ucapan terimakasih juga penulis ucapkan untuk tim laboratorium bakteriologi, Fakultas Ilmu Kesehatan, Universitas Maarif Hasyim Latif yang telah banyak membantu selama proses penelitian dari awal hingga akhir,

\section{DAFTAR PUSTAKA}

Adedeji G.B., Fagade O. G., Oyelade A.A. 2007. Prevalence of Pseudomonas aeruginosa in Clinical Samples and its Sensitivity to Citrus Extract. Af. J. Biomed RS. 10 : 183-187.

Akhi M.T., R. Ghotaslou, M. Asgharzadeh, M. Varshochi, T. Pirzadeh, M.Y. Memar, A.Z. Bialvaez, H.S.Y. Sofla and N. Alizadeh. 2015. Bacterial Etiology and Antibiotics Susceptibility Pattern of Diabeteic Foot Infections in Tabriz Iran. GMS Hygiene and Infection Control. 10 : 1-6.

Anathanarayan R. and jayarampaniker C.K., 2009. Text Book of Microbiology. $8^{\text {th }}$ Edition. India Universities Press.

Androulla E. 1989. Outbreaks of Human Infections Caused by Pyogenic Streptococci of Lencefield Group C and G. Journal of Medical Microbiology. 29: 207-219.

Anvarinejad M., G. Pouladfar, A. Japoni, S. Bolandparvaz, Z. Satiary, P. abbasi and J. Mardaneh. 2015. Isolation and Antibiotic Susceptibility of the Microorganism Isolated from Diabetic 
Foot Infection in Nemazee Hospital Southern Iran. Journal of Pathogenes. Pp. 1-7.

Chong L.V.H. and K. Soon. 2009. Pyogenic Liver Absscess as the First Manifestation of Hepatobiliary Malignancy. Hepatobiliary Pancreas Dis. Int. 8: 547-550.

Faden H., A.J. Lesse., J. Trask, J. Hill., D.J. Hees, D. Dryja. 2010. Importance of Colonization Site in the Current Epidemic of Staphylococcal Skin Abscesses. Pediatrics.

Hadadi A., H.O. Ghiasi, M. Hajabdolbaghi, M. Zandekarimi and R. hamidian. 2014. Diabetic Foot : Infections and outcomes in Iranian Admitted Patients. Jundishapur Journal of Microbiology. 7(7) : 1-4.

Koneman W.K., Allen S.D., Janda W.M., Schreckenberger P.C., propcop G.W., Woods G.L, Win W.C., and Jr. Philadelphia. 2005. Color Atlas and Text Book of Diagnostic Microbiology. $6^{\text {th }}$ Edition. Lippincort-ravea Publisher. Pp. 624-662.

Kumar A.R. 2013. Antimicrobial Sensitivity Pattern of Klebsiella pneumonia Isolated from Pus from Tertiarycar Hospital and Issues Related to the Rational Selection of Antimicrobials. Journal of Chemical and Pharmaceutical Research. 5(11): 326331.

Matsuura G.T. and N. Barg. 2013. Update on the Antimicrobial Management of Foot Infections in Patients with Diabetes. Clinical Diabetes. 31(2): 59-65.

Miller L.S. and john S.C. 2001. Immunity Againts Staphylococcus aureus Cutaneous Infections. Nature Reviews Immunology. 11:505-518.

Qureshi A.H., S. Rafi, S.M. Qureshi, and A.M. Ali. 2004. The Current Susceptibility Patterns of Methicillin Resistant Staphylococcus aureus to Conventional
Anti-Staphylococcus Antimicrobials at Rawalpindi Pakistan. Journal of Medical Sciences. $20: 361-364$.

Raytaker N.A., M.R. Choudari and S. Das. 2017. Antibiotic Profilling of Pseudomonas aeruginosa Isolates from Pus Sample of Rural Tertiary Care Hospital of Western Mahanashtra, Loni, India. Int. Jour. Of Research in Medical Sciences. 5(7): 3076-3081.

Sharma V., G. Parihar, V. Sharma and H. Sharma. 2015. A Study of Various Isolates from Pus Sample with Their Antibiogram from Jln Hospital Ajmen. IOSR Journal of Dental and Medical Sciences. 14(10): 64-68.

Singh S., M. Khare, R.K. Patidar, S. Bagde, K.N. Sahare, D. Dwevedi and V. Singh. 2013. Antibacterial Activities Against Pyogenic Pathogens. Int. Jour. Of Pharmaceutical Sciences and Research. 4(8):2974-2979.

Sriefungfung S., Chuntima T., Thitiya Y., Chertsak D. 2004. Prevalence and Antimicrobial Susceptibility of Pseudomonas aeruginosa Mucoidansd non-mucoidtype. Southeast Asian Journal Trop. Med. Public Health. 35(4): 893-896. 